\title{
PEMBELAJARAN MATEMATIKA MELALUI PENDEKATAN KETERAMPILAN METAKOGNITIF DENGAN MODEL ADVANCE ORGANIZER UNTUK MENINGKATKAN KEMAMPUAN BERPIKIR KRITIS MATEMATIK SISWA SMA
}

\author{
Masta Hutajulu
}

STKIP Siliwangi Bandung

masthahutajulu@yahoo.com

\begin{abstract}
This study was conducted to determine and examine the achievements and increasing critical thinking mathematical ability students metacognitive approaches with Advance Organizer Model and regular learning. This research is expected to contribute to teacher and student in mathematics learning approach Metakogntif skills with Advance Organizer models. Data collection techniques is used to the test. Results from this study is the Achievement and increasing students' critical thinking skills in math learning mathematics through metacognitive skills approaches with advanced models of learning organizer better than regular leraning.

Keywords: critical thinking mathematical ability, Metakogntif Approach, Advance Organizer model.
\end{abstract}

\begin{abstract}
Abstrak
Penelitian ini dilakukan untuk mengetahui dan menelaah pencapaian dan peningkatan kemampuan berpikir kritis matematik siswa pada pembelajaran matematika melalui pendekatan ketrampilan metakognitif dengan model advance organizer dan siswa yang memperoleh pembelajaran biasa. Penelitian ini diharapkan memberi kontribusi untuk setiap guru dan siswa pada pembelajaran matematika dengan pendekatan Ketrampilan Metakogntif dengan model Advance Organizer. Teknik pengumpulan data yang digunakan adalah dengan menggunakan tes. Hasil dari penelitian ini adalah Pencapaian dan peningkatan kemampuan berpikir kritis matematik siswa pada pembelajaran matematika melalui pendekatan ketrampilan metakognitif dengan model advance organizer lebih baik dari pembelajaran biasa.
\end{abstract}

Kata Kunci: Kemampuan berpikir kritis matematis, Pendekatan Metakogntif, Model Advance Organizer.

PENDAHULUAN

Pendidikan merupakan salah satu komponen yang sangat penting dalam pembentukan dan pengembangan kualitas Sumber Daya Manusia (SDM) dalam menghadapi 
era globalisasi. Sumber daya manusia yang dimaksudkan perlu memiliki keterampilan yang meliputi berpikir kritis, sistematis, logis, dan mampu bekerjasama, serta mengembangkan kreativitas dan inovasi serta kemampuan untuk berargumentasi atau mengemukakan ide-ide untuk memecahkan masalah yang terjadi dalam kehidupan. Untuk itu, pendidikan di Indonesia harus ditingkatkan supaya tercipta sumber daya manusia yang memiliki keterampilan-keterampilan tersebut.

Salah satu modal untuk menghadapi berbagai tantangan di era globalisasi ini adalah kemampuan berpikir kritis dan kreatif Matematik. Untuk mengolah keterampilan ini harus ditanamkan sejak dini seperti pendidikan di sekolah yang harus lebih ditingkatkan lagi.

Mengembangkan kemampuan berpikir kritis dan kreatif di kalangan masyarakat Indonesia merupakan hal yang sangat penting dalam era persaingan global, karena tingkat kompleksitas permasalahan dalam segala aspek kehidupan modern ini semakin tinggi. Harapan yang ingin dicapai bahwa dengan berpikir kritis dan kreatif masyarakat dapat mengembangkan diri mereka dalam membuat keputusan, penilaian, serta menyelesaikan masalah.

Kemampuan berpikir kritis dapat dikembangkan melalui kegiatan pembelajaran matematika karena tujuan pembelajaran matematika di sekolah menurut Depdiknas (2006) adalah: (1) memahami konsep matematika, menjelaskan keterkaitan antarkonsep dan mengaplikasikan konsep atau algoritma, secara luwes, akurat, efisien, dan tepat, dalam pemecahan masalah; (2) menggunakan penalaran pada pola dan sifat, melakukan manipulasi matematika dalam membuat generalisasi, menyusun bukti, atau menjelaskan gagasan dan pernyataan matematika; (3) memecahkan masalah yang meliputi kemampuan memahami masalah, merancang model matematika, menyelesaikan model dan menafsirkan solusi yang diperoleh; (4) mengkomunikasikan gagasan dengan simbol, tabel, diagram, atau media lain untuk memperjelas keadaan atau masalah, dan (5) memiliki sikap menghargai kegunaan matematika dalam kehidupan, yaitu memiliki rasa ingin tahu, perhatian, dan minat dalam mempelajari matematika, serta sikap ulet dan percaya diri dalam pemecahan masalah.

Dengan demikian, kemampuan berpikir kritis sangatlah penting untuk dikembangkan pada pembelajaran matematika secara formal baik itu di tingkat pendidikan dasar, pendidikan menengah, ataupun perguruan tinggi. apabila berpikir kritis dikembangkan, seseorang akan cenderung untuk mencari kebenaran, berpikir divergen (terbuka dan toleran terhadap ide-ide baru), dapat menganalisis masalah dengan baik, berpikir secara sistematis, penuh rasa ingin tahu, 
dewasa dalam berpikir, dan dapat berpikir kritissecara mandiri.

Kemampuan berpikir kritis dan kreatif matematik juga mempunyai karakteristik bahwa proses yang dilakukan berupa tindakan untuk menyadarkan kemampuan kognitif siswa, maka proses penyadaran kemampuan kognitif siswa ini didekati secara metakognitif. Dengan pendekatan ketrampilan metakognitif, siswa dipandu untuk dapat menyadari apa yang mereka ketahui dan apa yang mereka tidak ketahui serta bagaimana mereka memikirkan agar mereka dapat menyelesaikan suatu permasalahan yang dihadapi. Pembelajaran dengan pendekatan ketrampilan metakognitif dapat dijadikan sebagai upaya untuk meningkatkan kemampuan berpikir kritis matematik siswa.

\section{Penelitian Cardella-Ellawar} (Teong, 2000) menemukan bahwa siswa yang dilatih pembelajaran menangkap dan mengontrol proses kognitifnya sendiri lebih baik kemampuan kognitifnya daripada siswa yang tidak dilatih dalam memecahkan masalah matematika. Hasil penelitian Teong (2000) juga menemukan bahwa siswa yang proses dalam pembelajaran matematikanya memuat ketrampilan metakognitif menyadari proses kognitifnya selama memecahkan masalah; mereka terlihat lebih memungkinkan untuk dapat menangkap secara teratur proses berpikirnya dan proses tersebut terlihat memberikan kontribusi terhadap kesuksesan siswa dalam memecahkan masalah.

Aktivitas belajar matematika harus diupayakan dengan belajar bermakna, sehingga dapat membangun pola pikir dan nalar siswa dalam memecahkan masalah yang sedang dihadapinya. Strategi-strategi yang dilakukan untuk memecahkan masalah bergantung pada pengetahuan siswa yang berpikir secara sadar.

Pembelajaran menggunakan model advance organizer membuat belajar yang bersifat hafalan menjadi bermakna dengan cara menjelaskan konsep relevan yang ada dalam struktur kognitif siswa, sehingga siswa dapat memahami konsep lebih efektif dan efesien. Untuk memahami konsep agar efektif dan efesien diperlukan perencanaan pembelajaran yang sistematis agar proses pembelajaran menjadi bermakna. Jadi proses belajar tidak sekedar menghafal konsepkonsep atau fakta-fakta belaka, namun berusaha menghubungkan konsepkonsep tersebut untuk menghasilkan pemahaman yang utuh sehingga konsep yang dipelajari akan dipahami secara baik dan tidak mudah dilupakan.

Model advance organizer dirancang untuk memperkuat struktur kognitif siswa atau pengetahuan mereka tentang pelajaran tertentu dan bagaimana mengelola, memperjelas dan memelihara pengetahuan tersebut dengan baik. Dengan kata lain, struktur kognitif harus sesuai dengan 
jenis pengetahuan yang ada dalam pikiran, seberapa banyak pengetahuan tersebut dan bagaimana pengetahuan ini dikelola (Ausubel dalam Joyce, Weil \& Calhoun, 2000).

Ausubel (Joyce, Weil \& Calhoun, 2000) meyakini bahwa struktur kognitif yang ada dalam diri seseorang merupakan faktor utama yang menentukan apakah materi baru akan bermanfaat atau tidak dan bagaimana pengetahuan yang baru ini dapat diperoleh dan dipertahankan dengan baik. Sebelum guru menyajikan materi baru secara efektif, guru harus meningkatkan stabilitas dan kejelasan struktur siswa. Ini dapat dilakukan dengan memberikan mereka konsep-konsep yang dapat menentukan informasi untuk dipresentasikan pada mereka.

Kekuatan advance organizer terletak pada tujuan utamanya yakni pengembangan struktur kognitif dan menambah daya ingat terhadap informasi baru, sehingga advance organizer harus disusun berdasarkan pada konsep yang terdapat dalam kegiatan ilmu tersebut.

Secara umum tujuan advance organizer adalah menjelaskan, mengintegrasikan dan menginterkorelasikan materi dalam pembelajaran dengan materi yang dipelajari sebelumnya. Advance organizer membantu siswa membedakan materi baru dari materi yang sebelumnya dipelajari. Advance organizer yang paling efektif adalah menggunakan konsep, istilah-istilah, dan dalil-dalil yang sudah dikenal siswa serta diilustrasikan dengan analogi yang tepat. Tujuan ini tercapai jika pengembangan rencana pembelajaran dilakukan sesuai dengan tuntutan kurikulum, artinya kurikulum benar-benar berfungsi sebagai pedoman pengajaran.

Adapun kaitan antara pembelajaran matematika melalui pendekatan ketrampilan metakognitif dengan model advance organizer terhadap kemampuanberpikir kritis matematik, bahwa dalam pembelajaran melalui pendekatan ketrampilan metakognitif dengan model advance organizer, siswa diarahkan untuk mengkonstruksi sendiri konsep yang ingin dicapai. Pengkonstruksian diawali dengan memberikan suatu permasalahan, kemudian siswa merencanakan apa yang akan diperbuat agar permasalahan tersebut dapat diselesaikan, dengan melihat materi prasyarat yang harus siswa kuasai, apa yang dia tahu dan apa yang dia tidak tahu. Proses menghubungkan pengetahuan baru dengan pengetahuan yang sudah ada akan melibatkan motivasi, pengetahuan dan konsepsi awal yang akan menghasilkan pemaknaan dan pemahaman siswa dalam pembelajaran.

Aktivitas - aktivitas pada pembelajaran matematika melalui pendekatan ketrampilan metakognitif dengan model advance organizer dirancang untuk meningkatkan 
kejelasan dan kemantapan materi pembelajaran yang baru sehingga gagasan-gagasan yang hilang tidak terlalu banyak hanya karena disebabkan ketidakjelasan satu sama lain. Siswa seharusnya membedah materi tersebut saat mereka menerimanya dengan menghubungkan materi pembelajaran baru dengan pengalaman personal, struktur kognitif dan sikap kritis pada pengetahuan.

Pembelajaran melalui pendekatan ketrampilan metakognitif dengan model advance organizer inilah yang diteliti sebagai alternatif dalam upaya untuk meningkatkan kemampuan berpikir kritis matematik siswa. Penelitian ini bertujuan; 1) Untuk menelaah dan mengetahui perbedaan pencapaian kemampuan berpikir kritis matematik siswa pada pembelajaran matematika melalui pendekatan ketrampilan metakognitif dengan model advance organizer dan siswa yang memperoleh pembelajaran biasa. 2) Untuk menelaah dan mengetahui perbedaan peningkatan kemampuan berpikir kritis matematik siswa pada pembelajaran matematika melalui pendekatan ketrampilan metakognitif dengan model advance organizer dan siswa yang memperoleh pembelajaran biasa.

\section{KAJIAN TEORI}

\section{Kemampuan Berpikir Kritis Matematik}

Facione (Filsaime, 2008) membagi enam kemampuan berpikir kritis, yaitu interpretasi (interpretation), analisis (analysis), evaluasi (evaluation), penarikan kesimpulan (inference), penjelasan (explanation), dan kemandirian (selfregulation). Sedangkan Ennis (Innabi, 2003) membagi aspek berpikir kritis matematik ke dalam dua aspek yaitu aspek umum dan khusus . Aspek umum yang dimaksud meliputi kemampuan (abilities) dan pengaturan (dispositions), sedangkan aspek khusus yang terkait dengan materi matematika meliputi penguasaan konsep (concept), membuat generalisasi (generalizations), algoritma dan keterampilan (algorithms and skills), serta pemecahan masalah (problem solving).

Berkaitan dengan kemampuan berpikir kritis pada matematika, pengembangan berpikir kritis di dalam kelas (sekolah) mulai dicetuskan oleh Harlod Fawcett pada tahun 1938. Pengembangan berpikir kritis yang dilakukan oleh Fawcett adalah mencoba mengajar kemampuan berpikir kritis yang aktivitasnya seperti membandingkan, membuat kontradiksi, induksi, generalisasi, membuat pengkhususan, mengklalisifikasikan, membuat katagori, mengurutkan, memvalidasi, membuktikan, mengkaitkan, menganalisis, mengevaluasi, dan membuat pola, yang aktivitas-aktivitas dirangkaikan secara berkesinambungan (Appelbaum, 2004).

Jauh setelah idenya Fawcett, baru pada tahun 1989, NCTM dalam buku tahunannya "Curriculum and 
Evaluation Standards" nyarankan untuk mengembangkan kemampuan berpikir di dalam kelas (Appelbaum, 2004). Setelah itu mulai banyak penelitian dan pengembangan berpikir kritis dalam bidang matematika baik itu di tingkat internasional maupun nasional.

Menurut Innabi (2003)
indikator-indikator yang dapat
mengukur berpikir kritis dalam
matematika adalah indikator inti yang
diberikan oleh Ennis, yaitu konsep,
generalisasi, keterampilan dan
pemecahan masalah. Sedangkan berkaitan dengan pengembangan berpikir kritis dalam matematika menggunakan media elektronik untuk pembelajaran (e-learning), Glazer (2004) menggunakan tiga indikator yaitu:

1. Pembuktian adalah kemampuan untuk membuktikan suatu pernyataan secara deduktif (menggunakan teori-teori yang telah dipelajari sebelumnya)

2. Generalisasi adalah kemampuan untuk menghasilkan pola atas persoalan yang dihadapi untuk katagori yang lebih luas.

3. Pemecahan masalah adalah kemampuan mengidentifikasi unsur yang diketahui, yang ditanyakan, dan memeriksa kecukupan unsur yang diperlukan dalam soal; menyusun model matematika dan menyelesaikannya; serta memeriksa kebenaran hasil atau jawaban.
Adapun indikator yang digunakan pada penelitian ini adalah pembuktian, genelarisasi dan pemecahan masalah.

\section{Pembelajaran dengan Pendekatan Ketrampilan Metakognitif}

Pembelajaran dengan pendekatan ketrampilan metakognitif merupakan pembelajaran yang menanamkan kesadaran bagaimana merancang, memonitor, serta mengontrol tentang apa yang mereka ketahui, apa yang diperlukan untuk mengerjakan dan bagaimana melakukannya; menitikberatkan pada aktivitas belajar siswa; membantu dan membimbing siswa jika ada kesulitan, dan membantu siswa untuk mengembangkan konsep diri apa yang dilakukan pada saat belajar matematika.

Jika mengacu kepada pendapat Schoenfeld (1987), Blakey \& Spence (1990), Huit (1990) dan Meyer (2002), ketika metakognitif terlibat dalam proses pembelajaran, secara otomatis siswa akan aktif dalam berpikir. Proses yang aktif ini memberikan efek bagi siswa untuk berinteraksi baik secara internal maupun secara eksternal.

Ketrampilan metakognitif berperan untuk membimbing siswa dalam menyadari dan mengontrol proses interaksi dalam berpikir tersebut. Secara internal siswa akan membangun pengetahuan dengan menginteraksikan ide-ide dalam pikirannya berdasarkan pengetahuan awal (prior knowledge) yang telah 
dimiliki dan secara eksternal siswa membangun pengetahuan melalui interaksi dengan lingkungannya termasuk dengan teman-temannya untuk mencapai pemahaman yang lebih sempurna. Dengan demikian proses pembelajaran akan lebih efektif dalam mencapai tujuan. Pembelajaran dalam upaya penyadaran kognisi dan menumbuhkan keyakinan melalui pertanyaan-pertanyaan serta pengontrolan terhadap proses berpikir dalam membangun pengetahuan yang utuh merupakan pembelajaran dengan pendekatan ketrampilan metakognitif.

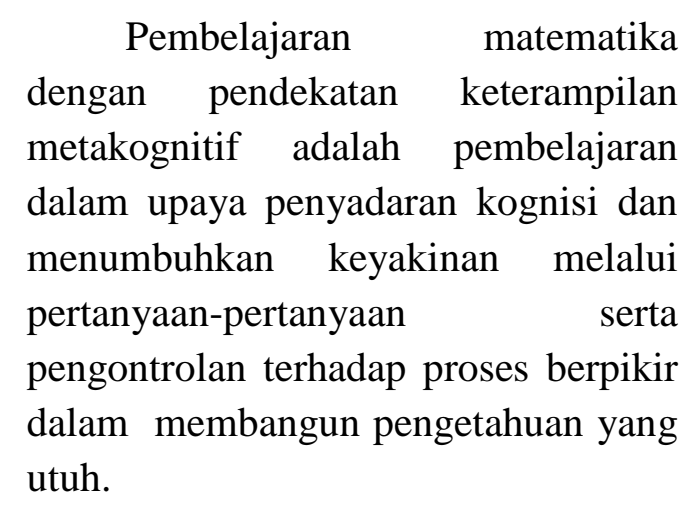

\section{Model Pembelajaran Advance Organizer}

Model pembelajaran advance organizer merupakan suatu cara belajar untuk memperoleh pengetahuan baru yang dikaitkan dengan pengetahuan yang telah ada pada pembelajaran, artinya setiap pengetahuan mempunyai struktur konsep tertentu yang membentuk kerangka dari sistem pemprosesan informasi yang dikembangkan dalam pengetahuan itu. Metode ini dikembangkan oleh David Ausubel dan menurutnya model ini adalah model belajar bermakna.
Dalam pembelajaran, guru berperan sebagai pengelola materi pelajaran dan menyajikan informasi melalui ceramah, membaca dan penyediaan tugas pada siswa dalam memadukan apa yang telah dipelajari. Dalam pendekatannya, guru bertanggung jawab dalam mengelola dan mempresentasikan apa yang akan dipelajari. Sedangkan peran utama siswa adalah menguasai gagasan dan informasi. Sementara pendekatanpendekatan induktif dapat menuntun siswa menemukan kembali konsepkonsep, maka advance organizer menyediakan konsep-konsep dan prinsip-prinsip pada siswa secara langsung (Ausubel dalam Joyce, Weil \& Calhoun, 2000)

Model pembelajaran advance organizer adalah suatu model pembelajaran yang dikembangkan untuk memperoleh pengetahuan baru yang dikaitkan dengan pengetahuan yang telah ada pada pembelajaran, artinya setiap pengetahuan mempunyai struktur konsep tertentu yang membentuk kerangka dari sistem pemprosesan informasi yang dikembangkan dalam pengetahuan itu dan bertujuan untuk memperkuat struktur kognitif pada siswa dalam memperoleh informasi baru, ide, ketrampilan, nilai dan cara pikir.

\section{METODE PENELITIAN \\ Metode dan Desain Penelitian}
Karakteristik yang akan diukur dalam penelitian ini adalah


kemampuan berpikir kritis matematik siswa. Pengukuran kemampuan matematika ini dilakukan terhadap kelompok siswa yang diberi perlakuan (eksperimen) dan kelompok siswa sebagai pembanding atau kontrol.

Desain yang digunakan dalam penelitian ini adalah penelitian semu (quasi eksperimen). Desain penelitian ini digunakan karena penelitian ini menggunakan kelompok kontrol, adanya dua perlakuan yang berbeda. Pengamatan dilakukan dua kali yaitu sebelum proses pembelajaran, yang disebut pretes dan sesudah proses pembelajaran, yang disebut postes. Secara singkat, disain penelitian tersebut adalah sebagai berikut:

$\begin{array}{lll}\mathrm{O} & \mathrm{X} & \mathrm{O} \\ \mathrm{O} & & \mathrm{O}\end{array}$

Keterangan :
$\mathrm{O}:$ Pretest = posttest (tes kemampuan berikir kritis matematik)

$\mathrm{X}$ : Perlakuan pembelajaran dengan menggunakan ketrampilan metakognitif dengan model advance organizer

\section{Tempat dan Waktu Penelitian}

Tempat Penelitian

Penelitian ini dilakukan di SMA Negeri 15 Bandung tahun ajaran 2015-2016pada kelas X yang terdiri dari 9 kelas.

\section{Waktu Penelitian}

Penelitian ini dilaksanakan pada bulan Mei sampai Juni 2016 pada kelas $\mathrm{X}$ yang terdiri dari 9 kelas.

\section{Subjek Penelitian}

Subjek dalam penelitian ini dikelompokkan dalam 2 kelas yaitu kelas X-6 yang dijadikan tempat kelas eksperimen atau kelompok eksperimen. Sedangkan kelas X-7 dijadikan sebagai kelas kontrol atau kelompok kontrol. Kelompok tersebut dipilih berdasarakan kelas yang diberikan kepada peneliti oleh guru mata pelajaran di sekolah tersebut.

\section{Instrumen Penelitian}

Instrumen yang dikembangkan dalam penelitian ini adalah tes tulis dalam bentuk uraian. Dalam hal ini, tes tulis yang diberikan akan digunakan untuk mengetahui kemampuan siswa dalam aspek-aspek berpikir kritis matematik. Tes tulis ini sebanyak 5soal yang mengukur aspek berpikir kritis matematik.

Sebelum tes dipergunakan dalam penelitian terlebih dahulu dibuat kisikisi soal yang dilanjutkan dengan menyusun soal beserta alternatif kunci jawaban dan aturan pemberian skor untuk tiap butir soal. Selanjutnya soal diujicobakan untuk mengetahui validitas, reliabilitas, tingkat kesukaran dan daya pembeda tiap butir soal tes yang akan digunakan dalam penelitian.

\section{HASIL PENELITIAN DAN PEMBAHASAN}

\section{Statistik Deskriptif.}

Deskripsi kemampuan berpikir kritis matematik siswa merupakan gambaran pencapaian dan peningkatan kemampuan berpikir kritis matematik siswasiswa berdasarakan jenis 
pendekatan pembelajaran (pendekatan ketrampilan metakognitif dengan model advance organizerdan biasa). Deskripsi statistika yang dimaksud meliputi rerata, standar deviasi serta jumlah siswa berdasarkan ketrampilan metakognitif dengan model advance organizerdan pembelajaran biasayang dapat dilihat dan disajikan dalam

Tabel 1 berikut:

Tabel 1

Hasil Tes Kemampuan Berpikir KritisMatematik Siswa

\begin{tabular}{|c|c|c|c|c|c|c|c|c|c|c|}
\hline \multirow{3}{*}{$\begin{array}{c}\text { Jenis } \\
\text { Kemampuan }\end{array}$} & \multicolumn{5}{|c|}{ Ketrampilan metakognitif dengan } & \multirow{2}{*}{\multicolumn{5}{|c|}{ Pendekatan Biasa }} \\
\hline & & & Model & Advanc & ganizer & & & & & \\
\hline & $\mathbf{N}$ & & Pretes & Postes & N-Gain & $\mathbf{N}$ & & Pretes & Postes & N-Gain \\
\hline \multirow{2}{*}{$\begin{array}{c}\text { Berpikir } \\
\text { Kritis }\end{array}$} & \multirow{2}{*}{30} & $\bar{x}$ & 5,40 & 17,67 & 0,854 & \multirow{2}{*}{30} & $\bar{x}$ & 6,13 & 13,07 & 0,51 \\
\hline & & $s$ & 2,76 & 1,88 & 0,11 & & $s$ & 2,59 & 2,63 & 0,13 \\
\hline
\end{tabular}

Setelah itu dilakukan analisis data pretes, postes dan gain yang bertujuan untuk menelaah dan mengetahui apakah perbedaan pencapaian dan peningkatan kemampuan berpikir kritis matematik siswa pada pembelajaran matematika melalui pendekatan ketrampilan metakognitif dengan model advance organizer lebih baik daripada siswa yang memperoleh pembelajaran biasa.

\section{Uji Normalitas}

Sebelum dilakukan uji hipotesis, terlebih dahulu dilakukan uji prasyarat yangmeliputi uji normalitas Lilliefors (uji kecocokan Kolmogorov-Smirnov) dan uji homogenitas (uji Levene). Hasil uji statistik terhadap normalitas data sampel ditampilkan dalam Tabel 2

berikut:

Tabel 2

Uji Normalitas Hasil Pretes, Postes dan Gain Ternormalisasi Kemampuan Berpikir Kritis Matematik

\begin{tabular}{llllr}
\hline & & \multicolumn{4}{c}{ Kolmogorov-Smirnov } \\
\cline { 3 - 5 } & Kelas & Statistic & Df & Sig. \\
\hline Pretes & kelas control & .140 & 30 & .138 \\
\cline { 2 - 5 } & kelas eksperimen & .122 & 30 & .200 \\
\hline Postes & kelas control & .157 & 30 & .057 \\
\cline { 2 - 5 } & kelas eksperimen & .137 & 30 & .157 \\
\hline Gain & kelas control & .105 & 30 & .200 \\
\cline { 2 - 5 } & kelas eksperimen & .137 & 30 & .154 \\
\hline
\end{tabular}

Berdasarkan Tabel 2, dapat dijelaskan bahwa untuk semua pretes, 
postes dan gain diketahui pada kelas kontrol dan eksperimen bahwa sig $>\alpha$ $=0,05$, maka $\mathrm{H}_{0}$ diterima. Hal ini berarti bahwa hipotesis nol yang menyatakan bahwa skor pretes, postes dan gain, pada kelas kontrol dan kelas eksperimen dan kelas kontrol berasal dari populasi yang berdistribusi normal.

\section{Uji Homogenitas}

Selanjutnya akan dilakukan uji homogenitas sebagai pada tabel 3 berikut:

\section{Tabel 3}

\section{Uji Homogenitas Variansi Hasil Pretes, Postes dan Gain Ternormalisasi Kemampuan Berpikir KritisMatematik}

\begin{tabular}{llccccc}
\hline & & Levene Statistic & df1 & df2 & \multicolumn{2}{c}{ Sig. } \\
\hline Pretes & Based on Mean & .073 & 1 & 58 & .787 \\
\hline Postes & Based on Mean & 4.546 & 1 & 58 & .073 \\
\hline Gain & Based on Mean & 1.838 & 1 & 68 & .180 \\
\hline
\end{tabular}

Berdasarkan Tabel 3, dapat dijelaskan bahwa untuk semua pretes, postes dan gain diketahui pada kelas kontrol dan eksperimen bahwa sig $>\alpha$ $=0,05$, maka $\mathrm{H}_{0}$ diterima. Hal ini berarti bahwa hipotesis nol yang menyatakan bahwa skor pretes, postes dan gain, pada kelas kontrol dan kelas eksperimen dan kelas kontrol berasal dari populasi yang bervariansi homogen.

\section{Uji Perbedaan Rerata}

Hasil perhitungan inferensial untuk uji perbedaan rerata dengan Uji$t$ ditampilkan oleh Tabel software SPSS $21.0 \quad$ Statistics.

Tabel 4.4

\section{Hasil Uji-tPretes, Postes dan N-Gain KemampuanBerpikir KritisMatematik}

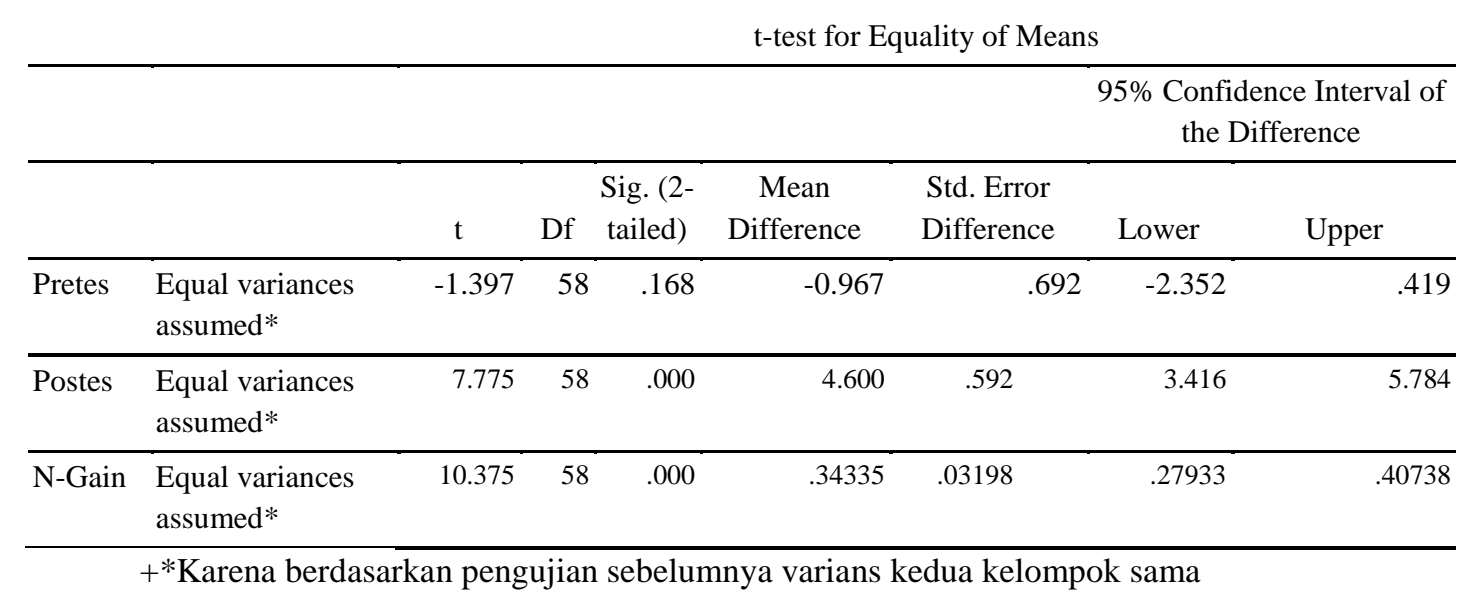


Pada pretes, uji- $t$ dilakukan dengan maksud menguji kesamaan dua rerata dari masing-masing kelompok. Penerimaan hipotesis nol pada pengujian ini mengidentifikasikan bahwa kelas manapun yang dipilih menjadi kelas kontrol atau eksperimen tidak akan terpengaruhi hasil penelitian. Atau dengan kata lain kemampuan awal kelas siswa eksperimen dan siswa kelas kontrol adalah sama.

Pada postes, uji- $t$ dilakukan dengan maksud menguji perbedaan dua rerata dari masing-masing kelompok. Penerimaan hipotesis satu pada pengujian ini mengidentifikasikan bahwa pencapaian kemampuan berpikir kritis matematik siswa secara bersama-sama pada pembelajaran matematika melalui pendekatan ketrampilan metakognitif dengan model advance organizer dan siswa yang memperoleh pembelajaran biasa.

Demikian juga pada N-gain, uji- $t$ dilakukan dengan maksud menguji perbedaan dua rerata dari masingmasing kelompok. Penerimaan hipotesis satu pada pengujian ini mengidentifikasikan bahwa peningkatan kemampuan berpikir kritis matematik siswa secara bersama-sama pada pembelajaran matematika melalui pendekatan ketrampilan metakognitif dengan model advance organizer dan siswa yang memperoleh pembelajaran biasa.

\section{KESIMPULAN DAN SARAN \\ Kesimpulan}

1. Pencapaian kemampuan berpikir kritis matematik siswa pada pembelajaran matematika melalui pendekatan ketrampilan metakognitif dengan model advance organizer lebih baik dari pembelajaran biasa.

2. Peningkatan berpikir kritis matematik siswa pada pembelajaran matematika melalui pendekatan ketrampilan metakognitif dengan model advance organizer lebih baik dari pembelajaran biasa.

\section{Saran}

1. Pembelajaran dengan menggunakan pendekatan ketrampilan metakognitif dengan model advance organizer.

2. Untuk penelitian lebih lanjut, disarankan untuk meneliti kemampuan matematik lainnya yang belum terjangkau oleh penulis, seperti kemampuan berfikir kreatif, multiple representative dan pengembangan dari kemampuan matematika tingkat tinggi.

\section{DAFTAR PUSTAKA}

Anderson, J.A. (2003).Critical Thinking Across the Disciplines. Makalah pada Faculty Development Seminar in New York City College of Technology, New York. 
Cardelle, M (1995). Effects of Metacogniotive Instruction on Low Achiever in Mathematics Problems. Journal of Teaching and Teacher Education.11(1)

Depdiknas. (2006). Peraturan Menteri Pendidikan Nasional Nomor 22 Tahun 2006 tentang StandarIsi. Jakarta: Depdiknas. Hacker, D.J. (2003). Metacognition : Definition and Empirical Foudation.[On Line]. Tersedia www.pysc.memphs.edu/tgr/m eta/htm. [16 September 2016]

Hassoubah, Z. I. (2004). Developing Creative and Critical Thinking Skill (Cara Berpikir Kreatif dan Kritis). Bandung : Yayasan Nuansa Cendikia

Huitt,W.G.(1997).Metacognition.[Onli ne].

Tersedia:http://Chiron.valdost a.edu/whuitt/col/cogsys/meta cogn.html. [16 Januari 2016]

Joyce, B., Weil, M., \& Calhoun, W. (2000). Models of Teaching (sixth Edition). A Pearson Education Company.

Meyer, M. C. (2002). To Foster Development of Cognitive Strategies, Use Embedded Scaffolding Techniques. [Online]. Tersedia: http://coe.sdsu.edu/EDTEC640 /POPsamples/mmeyer/mmeyer . $\mathrm{htm}$

NCTM, (2000). Mathematics Assessment a Practical Handbook for grade $6-8$. Reston: NCTM.
Schoenfeld, A.H. (1987). Metacognition and Epistemological Issues in Mathematical Understanding. Dalam Teaching and Learning Mathematical: Problem Solving. Laurence Eralbaum Associates: New Jersey.

Teong, S.K. (2000). The Effects of Metacognitive Training in Mathematical Word Problem Solving in a Computer Environment. Proceedings International Group for The Phsycology of Mathematics Education. Jepang: Hiroshima University.

Weinert, F.E. dan Kluwe, R.H. (1987). Metacognition, Motivation and Understanding. Hillsdale, New Jersey: Laurence Eralbaum Associates Publishers 